\title{
PERANCANGAN DAN ANALISIS KINERJA \\ PENGKODEAN AUDIO MULTICHANNEL DENGAN METODE CLOSED LOOP
}

\author{
Muhammad Sobirin dan Ikhwana Elfitri \\ Jurusan Teknik Elektro, Fakultas Teknik \\ Universitas Andalas
}

\begin{abstract}
Abstrak-Codec terbaru yang telah distandardisasi secara internasional adalah MPEG Surround. Namun sistem MPEG Surround open loop tidak memiliki kemampuan untuk meminimalkan error. Dalam penelitian ini dilakukan perancangan dan analisis kinerja pengkodean audio dengan metode closed loop pada MPEG Surround yang dapat meminimalisasi terjadinya error pada kompresi audio multichannel. Penerapan metode closed loop menyebabkan kenaikan nilai Signal to Noise Ratio (SNR). Nilai rata-rata SNR untuk semua bit rate yang diperoleh adalah $17.67385 \mathrm{~dB}$ untuk metode open loop dan $23.82338 \mathrm{~dB}$ pada metode closed loop. Kenaikan SNR tertinggi mencapai $82.72 \%$ dibandingkan dengan metode open loop. Nilai rata-rata kenaikan Objective Difference Grade (ODG) untuk seluruh sampel audio adalah sebesar 0.143917 . Secara perceptual objective test maupun subjective test menunjukkan bahwa audio hasil kompresi MPEG Surround dengan metode closed loop bekerja lebih baik daripada metode open loop. Secara keseluruhan, impairment pada audio hasil kompresi bersifat imperceptible pada bit rate 90 kbps atau yang lebih tinggi.
\end{abstract}

\section{Kata Kunci : Audio multichannel, MPEG Surround, Closed loop}

\begin{abstract}
The latest international standardized codec is MPEG Surround. But the open-loop system of the MPEG Surround not able to minimize errors. In this research, the design and performance analysis of the audio coding in MPEG Surround with closed-loop method which can minimize the occurrence of errors on multichannel audio compression was applied. The implementation of closed-loop method increase the value of Signal to Noise Ratio (SNR). The average value of SNR for all bit rate for open-loop and closed-loop method are $17.67385 \mathrm{~dB}$ and $23.82338 \mathrm{~dB}$, respectively. The highest SNR increase reaches $82.72 \%$ in comparison with the open-loop method. The average value increase of Objective Difference Grade (ODG) for the entire audio sample is equal to 0.143917. In perceptual objective test and subjective tests indicate that the MPEG Surround with closed-loop method works better than the openloop method. Overall, the impairment of audio compression is imperceptible at bit rate $90 \mathrm{kbps}$ or higher.
\end{abstract}

Keywords: Multichannel Audio, MPEG Surround, Closed loop

\section{PENDAHULUAN}

Perkembangan teknologi dan kualitas audio yang baik merupakan hal yang tak terpisahkan. Salah satunya adalah perkembangan teknologi multichannel audio coding. Dalam teknik audio coding terjadi proses kompresi dari sinyal audio yang direpresentasikan dengan jumlah bit sekecil mungkin dengan tetap mempertahankan kualitas sinyal audio dengan tujuan pentransmisian maupun penyimpanan.

Audio coding/compression masuk ke dalam bloksource coding. Beberapa contoh yang populer diantaranya Waveform Audio
(WAV), MPEG-1 layer 3 (MP3) dan MPEG Advance Audio Coding (AAC) atau biasa disebut MP4.

Teknologi multichannel audio coding bertujuan menghasilkan reproduksi suara yang lebih berkualitas dan nyata. Teknologi multichannel ini mampu memberikan hasil output audio yang membuat pendengar merasakan bahwa audio yang mereka dengar berasal dari sekeliling mereka sendiri sehingga memberikan kesan nyata.

Aplikasi multichannel audio coding menggunakan perangkat lunak atau coder untuk memproses audio orisinal menjadi audio dengan format multichannel. Beberapa jenis 
coder tersebut antara lain, DTS (Digital Theatre Sound), DD+ (Dolby Digital Plus), DD (Dolby Digital), AAC (MPEG 4 Advanced Audio Coding) dan WMA 9 (Windows Media Audio 9).

Codec terbaru yang telah distandardisasi secara internasional adalah MPEG Surround. MPEG Surround telah diadopsi oleh berbagai standard aplikasi seperti World DMB (DAB, $\mathrm{DAB}+, \mathrm{DMB}), \mathrm{ISDB}-\mathrm{Tmm}, \mathrm{DVB}, \mathrm{DRM}+, \mathrm{AT}-$ DMB, DLNA, OIPTV dan ATIS-IFF. Sistem MPEG Surround open loop tidak memiliki kemampuan untuk meminimalkan error. Oleh karena itu, dalam penelitian ini dilakukan perancangan dan analisis kinerja pengkodean audio dengan metode closed loop pada MPEG Surround yang diharapkan dapat meminimalisasi terjadinya error pada kompresi audio multichannel. Pengujian sistem dilakukan dengan melakukan listening test berupa tes subjektif kepada pendengar. Kemudian pendengar akan memberikan nilai untuk audio sampel. Hasil pengujian sistem tersebut kemudian di analisis dengan standar internasional.

\section{TINJAUAN PUSTAKA}

\subsection{Prinsip Dasar Perceptual Audio Coding}

Tugas utama dari sebuah coder adalah merepresentasikan data suatu sumber audio seefektif mungkin dengan tetap mempertahankan kualitas dari audio tersebut setelah dikompresi. Idealnya, Sinyal audio yang dikompresi harus terdengar identik dengan sinyal audio aslinya (perceptual transparency). Untuk tujuan ini, fokus perceptual audio coding lebih diutamakan untuk mengetahui kualitas dari audio yang optimal secara subjektif daripada pengukuran objektif seperti mean squared error (MSE) atau Signal-toNoise Ratio (SNR).

$$
\text { Perceptual audio coding }
$$
memanfaatkan pengetahuan tentang persepsi manusia terhadap suara dalam bidang Psychoacoustics yang memungkinkan untuk meneliti batasan yang dapat diterima manusia secara perceptual pada coding distortion dan pengkodean yang handal yang dapat meminimalkan gangguan subjektif yang ditimbulkan oleh coding distortion pada bitrate yang rendah.

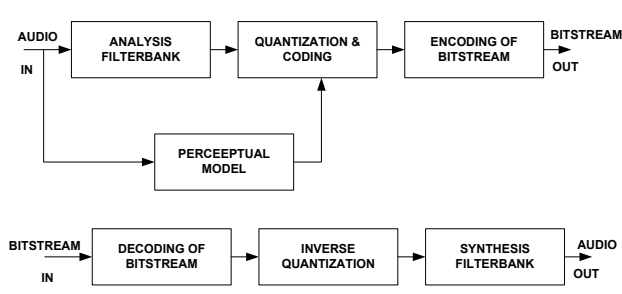

Gambar 1.Struktur Umum Coder dan Decoder pada Perceptual Audio

Dari Gambar 1 dapat dilihat blok diagram dasar dari perceptual audio coder monofonik yang terdiri dari beberapa komponen, yaitu [1]:

a. Analisis Filterbank

Sinyal input dipetakan ke representasi spektral subsample menggunakan beragam tipe analisis filterbank. Untuk alasan efisiensi pengkodean, skema pengkodean modern memiliki ciri penggunaan filterbank dengan sampling kritis (jumlah sampel input sama dengan koefisien spektral) dan window analisis yang tumpang-tindih antara frame analisis berikutnya. Contohnya terdapat pada modified discrete cosine transform (MDCT), filterbank fasa jamak (polyphase) atau struktur hybrid [9] [10].

\section{b.Perceptual Model}

Waktu dan frekuensi threshold sinyal diperkirakan dengan menggunakan perceptual model. Nilai ini menggambarkan error kuantisasi maksimum yang terdapat pada sinyal audio dengan tetap mempertahankan kualitas sinyal aslinya. Perceptual model pada audio coding bergantung pada efek psychoacoustics seperti masking dalam domain frekuensi, efek temporal masking, dan masking asimetris antara bunyi dan noise.

\section{c. Kuantisasi dan Pengkodean \\ Nilai spektral dikuantisasi dan dikodekan dengan presisi yang sesuai dengan estimasi masking threshold. Dengan cara ini, noise kuantisasi tersembunyi oleh sinyal yang ditransmisikan sehingga noise tidak terlihat setelah di decoding. Kuantisasi uniform dan}


non-uniform digunakan dalam konteks perceptual audio coding.

Pengurangan redudansi dapat dilakukan dengan teknik pengkodean entropi, seperti Huffman coding. Codec sering beroperasi di bawah keterbatasan bitrate yang ditetapkan pengguna, karena tidak mungkin untuk memenuhi dua batasan pada saat yang sama. Ketika masking threshold yang diestimasi menunjukkan target nilai minimum dari representasi sinyal yang dikodekan, coder sering kali beroperasi dibawah batasan bitrate yang dipilih user. Algoritma encoding yang baik harus mampu menghasilkan representasi solusi encoding yang dapat diterima untuk melihat kualitas audio di berbagai kasus. Disamping aspek perceptual model, aspek alokasi bit/alokasi noise merupakan bagian penting untuk optimasi audio coder.

\section{d. Bitstream Encoding}

Seluruh informasi yang relevan (nilai spektral yang dikodekan dan informasi tambahan) dipaketkan menjadi bitstream dan ditransmisikan ke decoder.

Proses yang sebaliknya berlaku pada decoder seperti tampak pada bagian bawah Gambar 2.1. Bitstream didekodekan dan diuraikan menjadi data spektral dan informasi tambahan. Kemudian diperoleh invers kuantisasi dari koefisien spektral terkuantisasi. Akhirnya, nilai spektral dipetakan kembali ke representasi domain waktu menggunakan sintesis filterbank.

\subsection{Struktur Encoder MPEG Surround}

Struktur encoder MPEG Surround ditunjukkan pada Gambar 2. Sebuah sinyal input multichannel diproses pertama kali oleh channel-dependent pregain. Penguatan ini memungkinkan penyesuaian level pada channel tertentu (misalnya, LFE dan surround) dalam downmix yang ditransmisikan.

Selanjutnya sinyal input diuraikan ke bentuk waktu atau frekuensi menggunakan analisis filterbank. Encoder spasial menghasilkan sinyal downmix dan parameter spasial untuk tiap bagian waktu dan frekuensi. Parameter ini dikuantisasi dan dienkoding menjadi parameter bitstream oleh encoder parameter Q. Downmix dikonversi ke domain waktu menggunakan sintesis filterbank.
Terakhir, postgain diaplikasikan untuk mengatur keseluruhan level sinyal downmix $[2]-[4][6]$.

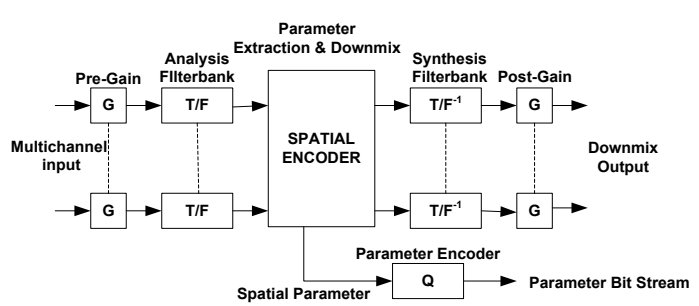

Gambar 2. Struktur Encoder MPEG Surround

\subsection{Struktur Decoder MPEG Surround}

Struktur decoder MPEG Surround ditunjukkan pada Gambar 3. Proses downmix pertama kali dilakukan pregain, yang merupakan kebalikan postgain pada encoder MPEG Surround. Kemudian sinyal input diproses dengan analisis filterbank yang identik dengan filterbank di encoder.

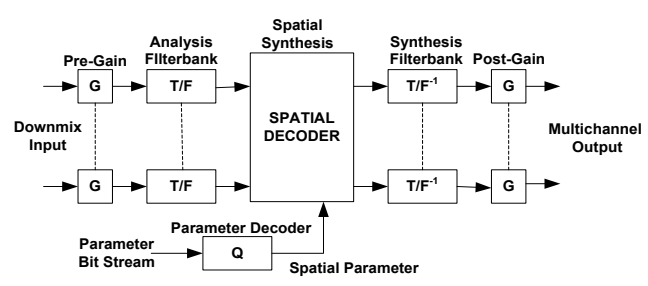

Gambar 3. Struktur Decoder MPEG Surround

Decoder spasial menghasilkan audio multichannel dengan mengatur sifat spasial pada parameter yang didekoding. Akhirnya, dengan menerapkan sintesis filterbank dan postgain (kebalikan encoder pregain) menghasilkan sinyal output multichannel dalam domain waktu [2][13][15].

\section{METODOLOGI}

\subsection{Proses dan Jenis Penelitian}

Berdasarkan tujuan dan manfaat penelitian, maka penelitian ini termasuk penelitian analisis. Maksudnya bahwa penelitian ini merupakan perancangan, pengujian dan analisa terhadap suatu aplikasi, dalam hal ini pengkodean audio multichannel. 
Proses penelitian perancangan dan analisis kinerja pengkodean audio multichannel dengan metode closed loop dapat dilihat pada Gambar 4.

\subsection{Metode Closed Loop pada Pengkodean Audio Multichannel}

Gambar 5 mengilustrasikan prinsip kerja metode closed loop yang akan dirancang. Model sistem yang dapat mensintesis sinyal dengan sejumlah set parameternya ditentukan[16]. Model sistem yang digunakan pada penelitian ini adalah MPEG Surround[17].

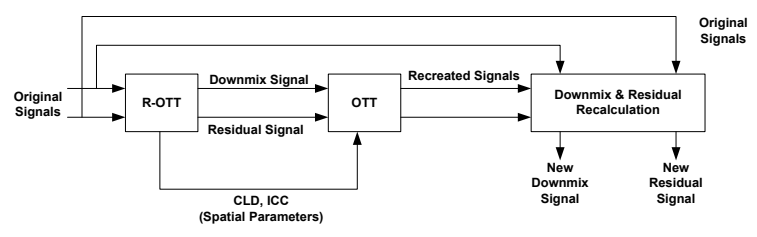

Gambar 5.Blok Diagram Metode Closed Loop

Perbedaan antara sinyal yang diobservasi dan sinyal hasil sintesis digunakan pada blok error minimization untuk menentukan parameter sistem yang optimal[16].

Konfigurasi spatial encoder yang diterapkan pada metode closed loop ini dapat diliuhat pada Gambar 6.

Penggunaan metode closed loop bertujuan untuk mengurangi error yang terjadi pada proses kuantisasi. Pada penelitian sebelumnya digunakan metode closed loop ROTT module. Penggunaan metode closed loop R-OTT ini menyebabkan akumulasi error yang besar karena sinyal audio diproses per blok ROTT. Oleh karena itu, dalam penelitian ini digunakan metode closed loop pada coding tree R-OTT yang telah diintegrasikan agar error tersebut dapat lebih diminimalkan.

Hybrid QMF tidak sesuai untuk digunakan pada metode closed loop, karena respon impuls dari analisis dan sintesis filterbanknya berbeda, sehingga menyebabkan delay. Namun hal ini tidak terjadi jika digunakan MDCT. Selain itu, penggunaan MDCT pada metode closed loop adalah karena kemampuannya dalam merekonstruksi sinyal dengan sempurna[14].

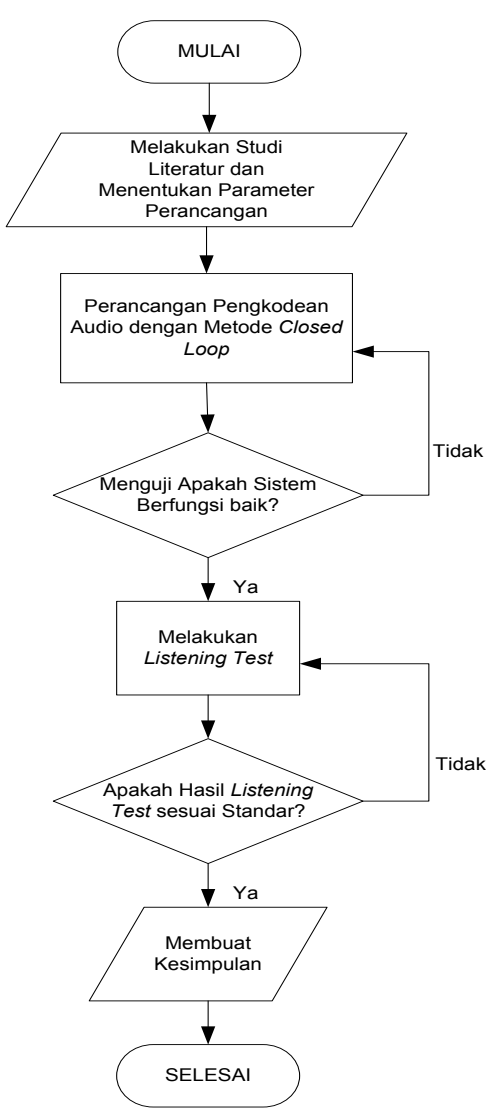

Gambar 4.Flow Chart Penelitian

Setiap blok R-OTT menghasilkan sinyal downmix, residual, dan spatial parameter (CLD dan ICC) seperti yang terlihat pada Gambar 3.2. Sinyal downmix dan residual pada blok R-OTT secara matematis dapat dinyatakan dengan persamaan-persamaan berikut ini:

$$
\begin{aligned}
d m_{2} & =\frac{x r_{1}+x r_{2}}{g_{a}+g_{b}} \\
r e s_{2} & =x r_{1}-g_{a} \cdot d m_{2}=g_{b} \cdot d m_{2}-x r_{2} \\
d m_{3} & =\frac{x r_{3}+x r_{4}}{g_{a}+g_{b}} \\
r e s_{3} & =x r_{3}-g_{a} \cdot d m_{3}=g_{b} \cdot d m_{3}-x r_{4} \\
d m_{1} & =\frac{d m_{2}+d m_{3}}{g_{a}+g_{b}} \\
r e s_{1} & =d m_{2}-g_{a} \cdot d m_{1}=g_{b} \cdot d m_{1}-d m_{3} \\
\text { mix } & =\frac{d m_{1}+x r_{5}}{g_{a}+g_{b}} \\
r e s_{0} & =d m_{1}-g_{a} \cdot \text { mix }=g_{b} \cdot \text { mix }-x r_{5}
\end{aligned}
$$

Untuk mengaplikasikan sistem closed loop, maka blok OTT ditempatkan di encoder untuk merekonstruksi sinyal audio. Output dari 
coding tree R-OTT berupa sinyal downmix, residual, dan spatial parameter (CLD dan ICC) kemudian diproses di blok OTT. Sinyal downmix dan residual pada blok OTT secara matematis dapat dinyatakan dengan persamaanpersamaan berikut ini:

$$
\begin{aligned}
& r d m_{1}=g_{a} \cdot m i x+r e s_{0} \\
& r d m_{2}=g_{a} \cdot r d m_{1}+r e s_{1 \text { new }} \\
& r d m_{3}=g_{b} \cdot r d m_{1}-r e s_{1 \text { new }} \\
& r e s_{2 \text { new }}=x r_{1}-g_{a} \cdot r d m_{2} \\
& r e s_{2 \text { new }}=g_{b} \cdot r d m_{2}-x r_{2} \\
& r e s_{3 \text { new }}=x r_{3}-g_{a} \cdot r d m_{3} \\
& r e s_{\text {3new }}=g_{b} \cdot r d m_{3}-x r_{4} \\
& r e s_{1 \text { new }}=d m_{2}-g_{a} \cdot r d m_{1} \\
& \text { res }_{1 \text { new }}=g_{b} \cdot r d m_{1}-d m_{3}
\end{aligned}
$$

Konstanta energi kedua sinyal $\left(\mathrm{g}_{\mathrm{a}}\right.$ dan $\mathrm{g}_{\mathrm{b}}$ ) dinyatakan oleh persamaan $15 \mathrm{a}$ dan $15 \mathrm{~b}$.

$$
\begin{aligned}
& g_{a}=\lambda_{1} \cos (\alpha+\beta) \\
& g_{b}=\lambda_{2} \cos (\alpha-\beta) \\
& \lambda_{1}{ }^{2}+\lambda_{2}^{2}=1 \\
& \lambda_{1}=\sqrt{\frac{10^{C L D} / 10}{1+10^{C L D / 10}}} \\
& \lambda_{2}=\sqrt{\frac{1}{1+10^{C L D} / 10}} \\
& \alpha=\frac{1}{2} \arccos (I C C) \\
& \beta=\tan \left[\frac{\lambda_{2}-\lambda_{1}}{\lambda_{2}+\lambda_{1}}\right] \arctan (\alpha) \\
& \mathrm{CLD}_{b}=10 \log _{10} \frac{\sigma_{X_{1, b}}^{2}}{\sigma_{X_{2, b}}^{2}}
\end{aligned}
$$

Dengan $\sigma_{X_{1, b}}^{2}$ adalah energi sinyal $X_{i}$ pada parameter band $b$,

$$
\begin{aligned}
\sigma_{X_{1, b}}^{2} & =\sum_{k} \sum_{m=m_{b}}^{m_{b}+1^{-1}} X_{i, m}[k] X *_{i, m}[k] \\
\operatorname{ICC}_{b} & =\operatorname{Re}\left\{\frac{\sum_{k} \sum_{m=m_{b}}^{m_{b}+1^{-1}} X_{1, m}[k] X *_{2, m}[k]}{\sigma_{\mathbf{x}_{1, b}} \sigma_{\mathbf{X}_{2, \mathbf{b}}}}\right\}
\end{aligned}
$$

Jika kita lakukan substitusi persamaan 14 ke persamaan 10 dan 11, maka diperoleh hasil sebagai berikut:

$$
\begin{aligned}
& \text { res }_{1 \text { new }}=d m_{2}-g_{a} \cdot r d m_{1} \\
& r d m_{2}=g_{a} \cdot r d m_{1}+r e s_{1 \text { new }} \\
& r d m_{2}=g_{a} \cdot r d m_{1}+d m_{2}-g_{a} \cdot r d m_{1} \\
& r d m_{2}=d m_{2} \\
& \text { res }_{1 \text { new }}=g_{b} \cdot r d m_{1}-d m_{3}
\end{aligned}
$$

\begin{tabular}{|c|c|c|c|}
\hline $\begin{array}{c}\text { Jenis } \\
\text { Audio }\end{array}$ & Codec & $\begin{array}{l}\text { Channel } \\
\text { Mode }\end{array}$ & $\begin{array}{c}\text { Bit } \\
\text { Rate/ } \\
\text { Channel } \\
\text { (kbps) }\end{array}$ \\
\hline Tertawa & \multirow{5}{*}{$\begin{array}{l}\text { MPEG } \\
\text { Surround }\end{array}$} & \multirow{5}{*}{$\begin{array}{c}5.1 \\
\text { channel }\end{array}$} & \multirow{5}{*}{$\begin{array}{c}40,60 \\
80,100 \\
120,140, \\
160 .\end{array}$} \\
\hline $\begin{array}{l}\text { Musik } \\
\text { Klasik }\end{array}$ & & & \\
\hline $\begin{array}{c}\text { Musik } \\
\text { Akustik }\end{array}$ & & & \\
\hline $\begin{array}{c}\text { Suara } \\
\text { Manusia }\end{array}$ & & & \\
\hline $\begin{array}{l}\text { Tepuk } \\
\text { tangan }\end{array}$ & & & \\
\hline
\end{tabular}

$r d m_{3}=g_{b} \cdot r d m_{1}-r e s_{1 \text { new }}$

$r d m_{3}=g_{a} \cdot r d m_{1}-\left(g_{b} \cdot r d m_{1}-d m_{3}\right)$

$r d m_{3}=d m_{3}$

Berdasarkan analisis secara matematis tersebut, dapat dilihat bahwa sinyal downmix pada blok R-OTT sama dengan OTT. Sehingga dapat dikatakan bahwa tidak terdapat error pada output encoder.

Hasil output encoder adalah sinyal downmix, sinyal residual, dan spatial parameter (CLD dan ICC) yang kemudian dikirimkan ke decoder untuk direkonstruksi kembali menjadi audio multichannel.

\subsection{Sampel Audio dan Subjek Listening Test}

Sampel audio yang digunakan adalah audio digital dengan format waveform (.wav). Jenis audio yang digunakan sebagai sampel ditunjukkan pada Tabel 1.

Tabel 1.Sampel Audio yang digunakan

Kelima jenis audio ini dikompresi dengan codec MPEG Surround standard dan closed loop.

Dalam praktiknya, terdapat dua jenis pendengar dalam pengujian sinyal audio, yaitu:

\section{Pendengar Ahli}

Pendengar ahli merupakan subjek tes yang memiliki kemampuan dalam bidang audio.Khususnya dalam pendeteksian gangguan pada sinyal audio.Sangat penting dalam pengujian subjektif dengan gangguan kecil untuk mendapatkan data penilaian dari subjek uji yang memiliki kemampuan dalam 


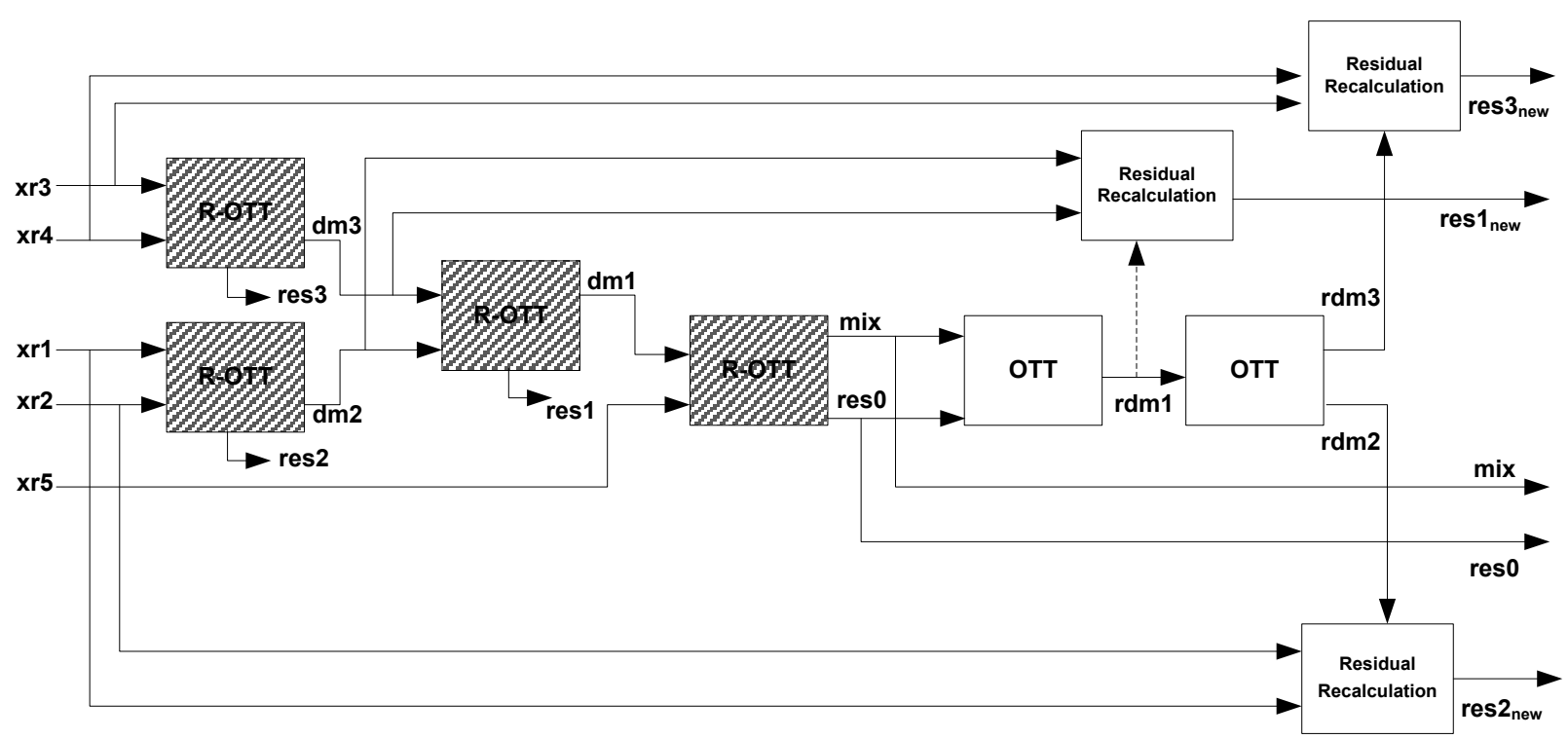

Gambar 6. Konfigurasi Spatial Encoder Metode Closed Loop

mendeteksi gangguan kecil sehingga data yang didapat memiliki kualitas yang tinggi dan akurat.

\section{Pendengar Tidak Ahli}

Pada rekomendasi ITU-R BS.1116-1 diatur beberapa proses pemilihan subyek tes[18].

\section{a. Pre-screening subjects}

Pre-screening subjects merupakan pemilihan subjek dengan mempertimbangkan pengalaman subjek tes dan kinerja dalam pengujian. Hal ini dilakukan untuk meningkatkan efisiensi pada pengujian yang dilakukan.

\section{b. Post-screening subjects}

Proses pemilihan subjek ini didasarkan pada dua faktor utama. Pertama didasarkan pada perbandingan inkonsistensi terhadap hasil rata-rata dari subjek yang bergantung pada kemampuan subjek untuk memberikan identifikasi yang benar. Kedua, faktor statistik dari subjek yang didapat dari faktor pertama. Kedua hal ini dapat memperjelas hasil pengujian yang dilakukan.

Subjek yang terlibat dalam pengujian ini adalah mahasiswa Jurusan Teknik ElektroUniversitas Andalas.Seluruh subjek diberi pelatihan atau training yang berhubungan dengan pengujian dan sistem audio multichannel. Ke-20 subjek yang dipilih, secara berurutan melakukan pengujian dan memberikan penilaian berdasarkan kualitas audio yang didengar.

\subsection{Teknik Analisis Pengujian}

Metode pengujian yang digunakan pada pengujian subjektif small impairment adalah metode yang disebut the double-blind triplestimulus with hidden reference.Metode ini memiliki kestabilan dan sensitivitas yang baik dan memungkinkan untuk menghasilkan data yang akurat.

Pada metode ini, digunakan tiga stimulus atau materi pengujian. Stimulus pertama atau stimulus A merupakan sinyal audio (sinyal asli) yang diketahui oleh subjek. Stimulus kedua dan ketiga (stimulus B dan stimulus $\mathrm{C}$ ) merupakan stimulus yang tidak diketahui oleh subjek (pendengar) dan diberikan secara acak kepada subjek pengujian.

Subjek akan diminta membandingkan sinyal audio stimulus B dengan sinyal audio stimulus $\mathrm{A}$, dan stimulus $\mathrm{C}$ dibandingkan dengan stimulus A. Berdasarkan standar yang ada pada rekomendasi ITU-R BS.1116-1 audio $\mathrm{B}$ dan $\mathrm{C}$ harus dapat dibedakan dengan audio $\mathrm{A}[5][18]-[25]$.

Pengujian dilakukan untuk mendapatkan grade terhadap hasil output audio yang dihasilkan dengan metode closed loop. Posisi pendengar dan posisi speaker diposisikan dalam keadaan tetap atau tidak berpindah. 
Dimana pendengar akan berada pada pusat area keluaran speaker yang diletakkan mengelilingi pendengar dengan sudut-sudut dan jarak tertentu[20-22].

\subsection{Akuisisi Data}

Kinerja sistem akan diujikan dan dianalisis dengan menggunakan penilaian subjektif dengan metode small impairment. Pendengar memberikan nilai untuk masingmasing audio yang diujikan dengan kriteria audio sesuai pada Tabel 2. Data tersebut diuji validitasnya menggunakan metode post screening.

Subjective Difference Grade (SDG) masing-masing subjek dihitung untuk mendapatkan nilai subject expertise. SDG merupakan selisih antara grade kualitas sinyal under test dengan grade kualitas sinyal asli[16]. Kedua sinyal diukur dengan menggunakan skala gangguan (1 sampai 5).Skala SDG yang digunakan berada pada rentang 0 hingga (-4).

Tabel 2. Skala Nilai Audio pada Pengujian Subjektif

\begin{tabular}{|c|c|}
\hline Impairment & Grade \\
\hline Imperceptible & 5 \\
\hline $\begin{array}{c}\text { Perceptible, but not } \\
\text { annoying }\end{array}$ & 4 \\
\hline Slightly Annoying & 3 \\
\hline Annoying & 2 \\
\hline Very Annoying & 1 \\
\hline
\end{tabular}

Persamaan 23 digunakan untuk normalisasi hasil subjek dengan tetap mempertahankan skala asli[23].

$$
Z_{i}=\frac{\left(x_{i}-x_{s i}\right)}{s_{s i}} \cdot s_{s}+x_{s}
$$

Keterangan :

$\mathrm{Z}_{\mathrm{i}}=$ Hasil normalisasi

$\mathrm{X}_{\mathrm{i}}=$ Nilai subjek ke-i

$\mathrm{X}_{\mathrm{si}}=$ Nilai rata-rata subjek ke-i pada sesi s

$\mathrm{X}_{\mathrm{s}}=$ Nilai rata-rata total subjek pada sesi $\mathrm{s}$

$\mathrm{S}_{\mathrm{s}}=$ Standar deviasi semua subjek pada sesi $\mathrm{s}$

$\mathrm{S}_{\mathrm{si}}=$ Standar deviasi subyek ke-i pada sesi s

Setelah nilai normalisasi didapat, kemudian dilanjutkan dengan menentukan nilai SDG atau nilai valid untuk codec yang diuji. Nilai SDG dihitung dengan mengurangkan nilai normalisasi sinyal undertest dengan sinyal asli. Persamaan yang digunakan adalah persamaan 24 untuk menentukan SDG tiap sampel.

$$
\mathrm{SDG}=\mathrm{Z}_{\mathrm{i} \text { (undertest })}-\mathrm{Z}_{\mathrm{i} \text { (original) }}
$$

Setelah didapat nilai SDG kemudian dapat dilakukan analisa hasil pengujian.Data SDG yang didapat harus disajikan ke dalam nilai selang kepercayaan (confidence interval). Nilai ini didapat dari standar deviasi dan besar data sampel yang digunakan dengan besar probabilitas confidence interval yang digunakan pada pengujian adalah $90 \%$. Hal ini dilakukan untuk menentukan rentang nilai ratarata data yang didapat memiliki kemungkinan populasi nilai yang masuk pada rentang $90 \%$.

$$
\begin{aligned}
& \delta=\alpha \frac{s}{\sqrt{N}} \\
& \alpha=1-\text { Prob. } \delta
\end{aligned}
$$

Keterangan :

$\delta=$ Confidence Interval

$\alpha=$ level signifikan yang digunakan

$\mathrm{S}=$ Standar deviasi

$\mathrm{N}=$ Besar data sampel

\section{HASIL DAN PEMBAHASAN}

Pengukuran SNR dilakukan untuk mengevaluasi keseluruhan kinerja dari rancangan pengkodean audio multichannel metode closed loop dengan bit rate yang bervariasi dan membandingkannya dengan kinerja metode open loop. 
Tabel 3. Perbandingan Kinerja Sistem MPEG Surround dengan Metode berbeda

\begin{tabular}{|c|c|c|c|c|c|c|}
\hline \multirow[t]{2}{*}{ No. } & \multirow[t]{2}{*}{ Audio } & \multirow{2}{*}{$\begin{array}{l}\text { Bitrate/ } \\
\text { Chamnel } \\
\text { (kbps) }\end{array}$} & \multicolumn{2}{|c|}{ Open Loop } & \multicolumn{2}{|c|}{ Closed Loop } \\
\hline & & & $\overline{O D G}$ & $\begin{array}{l}\text { SNR } \\
\text { (dB) }\end{array}$ & $\overline{O D G}$ & $\begin{array}{l}\text { SNR } \\
\text { (dB) }\end{array}$ \\
\hline \multirow[t]{7}{*}{1.} & \multirow{7}{*}{$\begin{array}{l}\text { Tephlk Tans9o } \\
\text { (spplsuse.wov) }\end{array}$} & 40 & -3.3646 & $\frac{1.1}{4.1295}$ & -3.3646 & $\frac{1.11}{4.1509}$ \\
\hline & & 60 & -1.9953 & 10.2972 & -1.8574 & 10.4734 \\
\hline & & 80 & -1.2313 & 16.3409 & -0.9934 & 17.2262 \\
\hline & & 100 & -0.4987 & 19.1782 & -0.1792 & 21.0822 \\
\hline & & 120 & -0.1756 & 19.9438 & 0.0027 & 22.3759 \\
\hline & & 140 & -0.034 & 22.0885 & 0.0100 & 27.2019 \\
\hline & & 160 & -0.0458 & 22.4091 & 0.0138 & 28.2889 \\
\hline 2. & \multirow{7}{*}{$\begin{array}{l}\text { Musik Klssik } \\
\text { (vivaldi.wsv) }\end{array}$} & 40 & -3.5312 & 8.6758 & -3.5537 & 9.0449 \\
\hline & & 60 & -2.2654 & 15.8 & -1.9791 & 18.8109 \\
\hline & & 80 & -0.9274 & 18.2949 & -0.5538 & 26.5909 \\
\hline & & 100 & -0.3756 & 18.6255 & -0.0529 & 28.7195 \\
\hline & & 120 & -0.2467 & 18.7129 & -0.0288 & 29.4535 \\
\hline & & 140 & -0.1287 & 19.0119 & 0.0123 & 33.9172 \\
\hline & & 160 & -0.0821 & 19.0519 & 0.0866 & 34.8112 \\
\hline \multirow[t]{7}{*}{3.} & \multirow{7}{*}{$\begin{array}{l}\text { Musik Alkustik } \\
\text { (drum.wov) }\end{array}$} & 40 & -2.6976 & 12.2158 & -2.6243 & 12.9610 \\
\hline & & 60 & -1.4606 & 17.1580 & -1.2808 & 20.3650 \\
\hline & & 80 & -0.6216 & 19.79 & -0.4704 & 26.2351 \\
\hline & & 100 & -0.2690 & 20.6121 & -0.0664 & 28.9109 \\
\hline & & 120 & -0.1510 & 20.9611 & 0.0236 & 30.2002 \\
\hline & & 140 & -0.0787 & 21.3035 & 0.0206 & 32.9345 \\
\hline & & 160 & -0.0524 & 21.3831 & 0.0653 & 33.7736 \\
\hline \multirow[t]{7}{*}{4.} & \multirow{7}{*}{$\begin{array}{c}\text { Tertawg } \\
\text { (lsughter.wov) }\end{array}$} & 40 & -3.2689 & 6.9275 & -3.2695 & 7.0688 \\
\hline & & 60 & -1.9942 & 14.8932 & -1.8274 & 15.9513 \\
\hline & & 80 & -0.9331 & 19.0386 & -0.7203 & 22.7019 \\
\hline & & 100 & -0.3176 & 20.1968 & -0.0567 & 25.6868 \\
\hline & & 120 & -0.1043 & 20.2782 & 0.1044 & 25.8868 \\
\hline & & 140 & 0.0187 & 21.1445 & 0.0313 & 30.0361 \\
\hline & & 160 & 0.0502 & 21.2935 & 0.0667 & 31.2502 \\
\hline \multirow[t]{7}{*}{5.} & \multirow{7}{*}{$\begin{array}{l}\text { S49ra Manusia } \\
\text { (talking.wsv) }\end{array}$} & 40 & -3.0417 & 9.1586 & -3.1776 & 8.8881 \\
\hline & & 60 & -1.9278 & 15.6802 & -1.7814 & 17.6299 \\
\hline & & 80 & -0.7610 & 19.6534 & -0.5646 & 25.6300 \\
\hline & & 100 & -0.2588 & 20.5830 & -0.1058 & 28.4129 \\
\hline & & 120 & -0.1406 & 20.9723 & -0.0061 & 30.0771 \\
\hline & & 140 & -0.0776 & 21.3289 & 0.0195 & 32.9838 \\
\hline & & 160 & -0.0537 & 21.4523 & 0.0508 & 34.0868 \\
\hline
\end{tabular}

Berdasarkan hasil pengujian dan pengolahan data, didapat data SNR yang menyatakan kualitas metode yang diterapkan pada MPEG Surround yang dapat dilihat pada Tabel 3.

Dari Gambar 7 dapat dilihat bahwa pada metode closed loop yang diterapkan pada MPEG Surround menyebabkan kenaikan SNR jika dibandingkan dengan metode open loop. Persentase kenaikan ini menjadi semakin tinggi jika bit rate dinaikkan. Kenaikan SNR terendah pada audio 'Tepuk Tangan' dengan bitratel channel $40 \mathrm{kbps}$, yaitu $0.52 \%$. Sedangkan kenaikan SNR tertinggi pada audio 'Musik Klasik'dengan bitrate/ channel $160 \mathrm{kbps}$, yaitu $82.72 \%$. Persentase kenaikan SNR rata-rata untuk seluruh sampel audio adalah sebesar $30.90528 \%$.

\section{SNR Audio Rata-Rata}

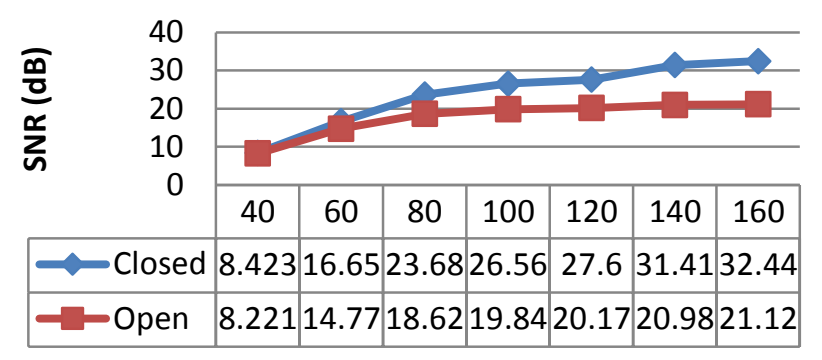

Gambar 7. Perbandingan Nilai SNR

Tujuan dari tes objektif adalah untuk mengestimasi kualitas perseptual dari rancangan pengkodean audio dengan bit rate yang bervariasi. Belum ada tes objektif untuk sinyal audio multichannel kualitas tinggi. Sehingga dapat disesuaikan dengan perceptual evaluation of audio quality (PEAQ)[25], rekomendasi ITU-R BS.1387-1 untuk penilaian sinyal audio mono, dan berdasarkan proses standarisasi yang ada dilakukan untuk penilaian audio multichannel[26]. Sebuah software yang dikembangkan oleh McGill University[27] digunakan untuk menghitung nilai ODG.

Sama halnya dengan nilai SNR, nilai ODG pada MPEG Surround dengan menggunakan metode closed loop secara keseluruhan juga lebih baik daripada dengan menggunakan metode open loop. Nilai rata-rata kenaikan ODG untuk seluruh sampel audio adalah sebesar 0.143917 .

Berdasarkan Gambar 8 dapat dilihat bahwa hasil pengujian yang didapat kualitas sampel audio yang paling baik adalah 'Suara Manusia' dengan nilai SDG yang didapat sebesar 0.34, dan nilai SDG subjek yang didapat berada pada rentang 0.44 untuk nilai maksimum dan 0.24 untuk nilai minimum. Rentang ini disebut dengan confidence interval, confidence interval yang ditetapkan pada pengujian ini sebesar 90\%.Confidence interval menggambarkan bahwa score SDG yang didapat pada pengujian yang dilakukan akan berada pada rentang tersebut. 


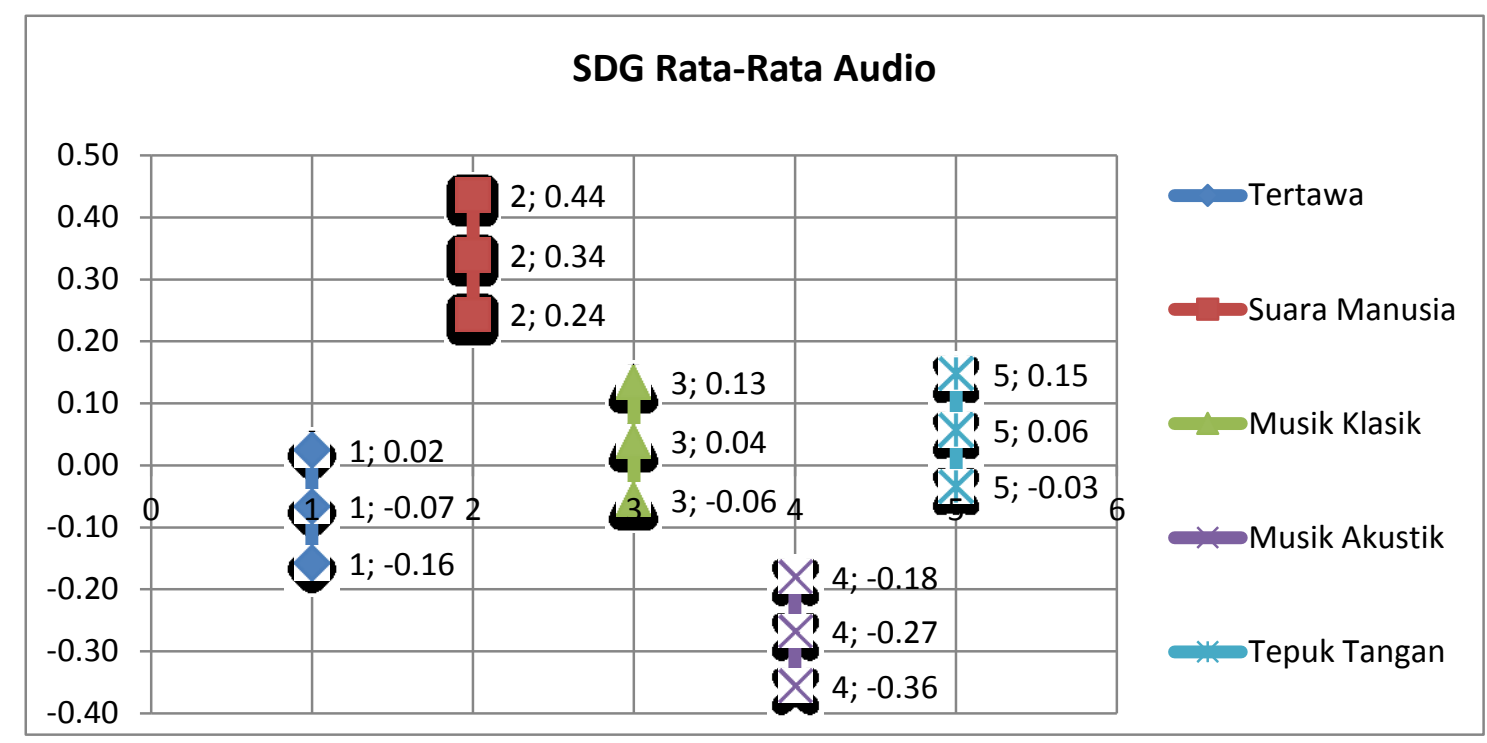

Gambar 8.Grafik SDG Rata-Rata Audio

\section{KESIMPULAN}

Berdasarkan penelitian yang telah dilakukan, maka diperoleh kesimpulan:

1. Metode closed loop pada MPEG Surround memiliki kinerja yang jauh lebih baik dibandingkan dengan metode open loop. Hal ini dapat dilihat dari persentase kenaikan Signal to Noise Ratio (SNR) yang signifikan, yaitu mencapai $82.72 \%$. Dan persentase kenaikan parameter ini semakin tinggi jika bit rate channelnya dinaikkan.

2. Persentase kenaikan SNR rata-rata untuk seluruh sampel audio adalah sebesar $30.90528 \%$.

3. Sama halnya dengan nilai SNR, nilai ODG pada MPEG Surround dengan menggunakan metode closed loop secara keseluruhan juga lebih baik daripada dengan menggunakan metode open loop. Nilai rata-rata kenaikan ODG untuk seluruh sampel audio adalah sebesar 0.143917.

4. Berdasarkan listening test yang dilakukan diperoleh bahwa kualitas sampel audio hasil kompresi yang paling baik adalah 'Suara Manusia' dengan nilai SDG rata-rata dari seluruh subjek sebesar 0.34, dan confidence interval nilai SDG subjek yang diperoleh berada pada rentang 0.44 untuk nilai maksimum dan 0.24 untuk nilai minimum.

5. Secara perceptual objective test maupun subjective test menunjukkan bahwa audio hasil kompresi MPEG Surround dengan metode closed loop bekerja dengan baik.
Secara keseluruhan, impairment pada audio hasil kompresi bersifat imperceptible pada bit rate 90 kbps atau yang lebih tinggi. Hal ini menunjukkan bahwa tujuan penelitian telah tercapai, yaitu kompresi audio dengan tetap mempertahankan kualitasnya.

\section{DAFTAR PUSTAKA}

[1] Herre, Jurgen. 2002. Audio Coding-an-All Around Entertainment Technology. AES 22nd International Conference in Virtual, Synthetic and Entertainment Audio, Finlandia. nt

[2] Breebaart, Jeroen dkk. 2007. Background, concept, and Architecture for the Recent MPEG Surround Standard on Multichannel Audio Compression. J. Audio Eng. Soc., Vol. 55, No. 5.

[3] Breebaart, Jeroen. 2007. Analysis and Synthesis of Binaural Parameters for Efficient 3D Audio Rendering in MPEG Surround. Proceeding IEEE International Conf. on Multimedia Expo.

[4] Bosi, Marina dan Richard E. Goldberg. 2003. Introduction to Digital Audio Coding and Standards. Netherlands: Kluwer Academic Publishers.

[5] Erne, Markus. 2001. Perceptual Audio Coders "What to Listen For". AES 111th Convention Paper, New York, USA.

[6] http://www.mpegsurround.com/ diakses pada 03/11/2013 5:40 PM

[7] Hull, Joseph. 1999.Surround Sound: Past, Present and Future. San Francisco: Dolby Laboratories Inc. 
[8] Fuchs, Harald., Korte, Okaf., Hilpert, Johannes. 2009.Digital Broadcasting with MPEG Surround. Fraunhofer IIS.

[9] Herre, Jurgen dkk. 2005. The Reference Model Architecture for MPEG Spatial Audio Coding. AES $118^{\text {th }}$ Convention Paper, Barcelona, Spain.

[10] Breebaart, Jeroen dkk. 2005. MPEG Spatial Audio Coding/ MPEG Surround: Overview and Current Status. AES $119^{\text {th }}$ Convention Paper, New York, USA.

[11] Engdegard, Jonas dkk. 2008. Spatial Audio Object Coding (SAOC) - The Upcoming MPEG Standard on Parametric Object Based Audio Coding. AES $124^{\text {th }}$ Convention Paper, Amsterdam, The Netherlands.

[12] Elfitri, Ikhwana. 2009. Spatial Audio Coding. TeknikA, No. 32 Vol. 1 Thn XVI

[13] Herre, Jurgen dkk. 2008. MPEG Surround - The ISO/MPEG Standard for Efficient and Compatible Multichannel Audio Coding. J. Audio Eng. Soc., Vol. 56, No. 11.

[14] Elfitri, Ikhwana., Shi, Xiyu., Kondoz, Ahmet. 2013. Analysis by Synthesis Spatial Audio Coding. IET Signal Process., pp.1-8.

[15] Breebaart, Jeroen dkk. 2006. Multichannel goes Mobile MPEG Surround Binaural Rendering. AES $29^{\text {th }}$ International Conference, Seoul, Korea.

[16] Elfitri, Ikhwana., Günel, Banu., M. Kondoz., Ahmet. 2011. Multichannel Audio Coding Based on Analysis by Synthesis.Proceedings of the IEEE, Vol. 99, No. 4.

[17] ISO/IEC 23003-1. 2007. Information Technology - MPEG Audio Technologies, Part 1: MPEG Surround.

[18] ITU. 1997. Rec ITU-R BS.1116-1: Methods For The Subjective Assessment Of Small Impairments In Audio Systems Including Multichannel Sound Systems.

[19] Saputra, Rio. 2011. Perancangan Sistem Pengenalan Ucapan Tipe Connected Word Dengan Metode MFCC dan Hidden Markov Model (HMM) untuk Mengakses Aplikasi Komputer. Padang : Universitas Andalas.

[20] Mason, Andrew dkk. 2007. EBU Test of Multi-Channel Audio Codecs. AES $122^{\text {nd }}$ Convention Paper, Vienna, Austria.
[21] Herrero, Carlos. 2007. Subjective and Objective Assessment of Sound Quality: Solutions and Applications. HUT, Telecommunications Software and Multimedia Laboratorio.

[22]Bosi, Marina. 2000. High-Quality Multichannel Audio Coding Trends and Challenges. J. Audio Eng. Soc., Vol. 48, No. 6.

[23] ITU. 2003. Rec. ITU-R BS.1284-1: General Methods for The Subjective Assessment of Sound Quality.

[24]Watanabe, Kaoru. Objective perceptual audio quality measurement method.Broadcast Technology no.35, Combined Issue Autumn 2008-Winter 2009

[25] ITU-R BS.1387-1: 'Method for Objective Measurements of Perceived Audio Quality', 2001.

[26] Liebetrau, J., Sporer, T., Kampf, S., Schneider, S.: 'Standarization of PEAQMC: Extension of ITU-R BS.1387 to Multichannel Audio'. Presented at AES $40^{\text {th }}$ Int. Conf, Spatial Audio: Sense the Sound of Space, Tokyo, Japan, October 2010.

[27] Kabal, P.: 'An examination and interpretation of ITU-R BS.1387: perceptual evaluation of audio quality', Telecommunication and Signal Processing Laboratory, Department of Electrical and Computer Engineering, McGill University (URL: $\quad$ http://wwwmmsp.ece.mcgill.ca/documents/Software/)

[28] Marston, D., Kozamernik, F., Stoll, G., Spikofski, G.:'Further EBU test of multichannel audio codecs'. Presented at the 126th Convention of the Audio Engineering Society, Munich, Germany, May 2009

\section{Biodata Penulis}

Muhammad Sobirin, Lahir di Medan 22 Juli 1989. Memperoleh gelar Sarjana Teknik pada tahun 2011 dari Departemen Teknik Elektro, Universitas Sumatera Utara, Konsentrasi Teknik Telekomunikasi.Saat ini sedang menempuh pendidikan di Magister Teknik Elektro, Universitas Andalas, Konsentrasi Teknik Telekomunikasi dan Multimedia. 